\title{
JOINT FLUID PRESSURE IN CHRONIC KNEE EFFUSIONS
}

\author{
BY \\ D. E. CAUGHEY AND E. G. L. BYWATERS \\ Rheumatism Research Unit (Medical Research Council), Canadian Red Cross Memorial Hospital, \\ Taplow, Berkshire
}

This study was undertaken to determine pressure changes within the knee joint under various experimental conditions. All the knees studied were the seat of chronic effusions secondary to rheumatoid arthritis, psoriatic arthritis, or degenerative joint disease. Aspirations were performed becaluse of persistent pain and limitation of movement of the joint.

\section{Material}

21 patients were studied, one of them on two occasions. In the majority, arthritis had been present for a number of years.

\section{Method}

With sterile precautions and after infiltration with local anaesthetic, a special type of needle was introduced into the lateral aspect of the knee near the upper border of the patella. This needle (S.W.G. 18, Down Bros., with a short bevel and perforations made in the sides $0.5 \mathrm{~cm}$. from the point to prevent blockage) had a tap and a side-arm. A manometer filled with normal saline was attached to the side-arm and the tap was opened. The manometer level fell rapidly and the pressure equalized with the atmospheric pressure with a minimal loss of joint fluid (Fig. 1, opposite).

The tap was closed and the initial readings in millimetres of saline and joint fluid were taken with the limb at rest. The pressure was then opposed by air pressure generated by a sphygmomanometer bulb communicating by a $\mathrm{Y}$-tube with a sphygmomanometer. Communication between the two systems was interrupted by a sterile cotton wool plug. The manometer recorded in $\mathrm{mm}$. $\mathrm{Hg}$ the pressure required to maintain the saline level at the zero point. Thus a null-point method of recording pressures was used. A strain-gauge method had been used initially but was discarded because it did not give sufficient sensitivity over the wide range of pressures that were recorded.

Pressures were measured in the supine position, at rest, with a venous cuff applied to the thigh at $70 \mathrm{~mm}$. $\mathrm{Hg}$ and with maximal quadriceps contraction. The patient then stood by the couch and readings were taken with the leg hanging and with the leg bearing weight; in some cases readings were taken with the leg bearing weight and maximally braced.

The procedure took 45 to 60 minutes, and afterwards joint fluid was taken for culture and $40 \mathrm{mg}$. depot methyl prednisolone was introduced. No growth of organisms was recorded in the 22 joints examined.

\section{Results}

Of the 22 joints, six were excluded from the series because of blockage of the needle with large fibrin clots, other technical difficulties, or inability of the patient to relax adequately. Apprehension, or anything leading to a slight bracing of the knee and, with it, quadriceps contraction, produced considerable elevation of pressure.

Each reading was estimated three times except for a few which were estimated twice. The data from each patient are arranged in the Table (opposite) in the order of the volume of the effusions.

It was found that the mean values at rest varied from 6 to $33 \mathrm{~mm}$. Hg. The patient with the highest reading had only a moderately tense effusion, but had great difficulty in relaxing. When a venous cuff was applied to the thigh the pressure rose in all but one case, but this was not a constant increment. With quadriceps contraction there was a marked increase in pressure in all cases.

When the patient stood by the couch, bearing his weight on the other leg, an increase in pressure occurred in the knee in eleven cases. When the weight was borne equally on both legs an increase occurred in all cases. All but one of eight cases tested with weight bearing and bracing back of the knees, showed a large increase in pressure.

In Subject 4 the difference in the pressure in the braced knee between the supine and erect positions was possibly due to a communicating Baker's cyst which was compressed against the table in the supine position but not in the erect posture. 


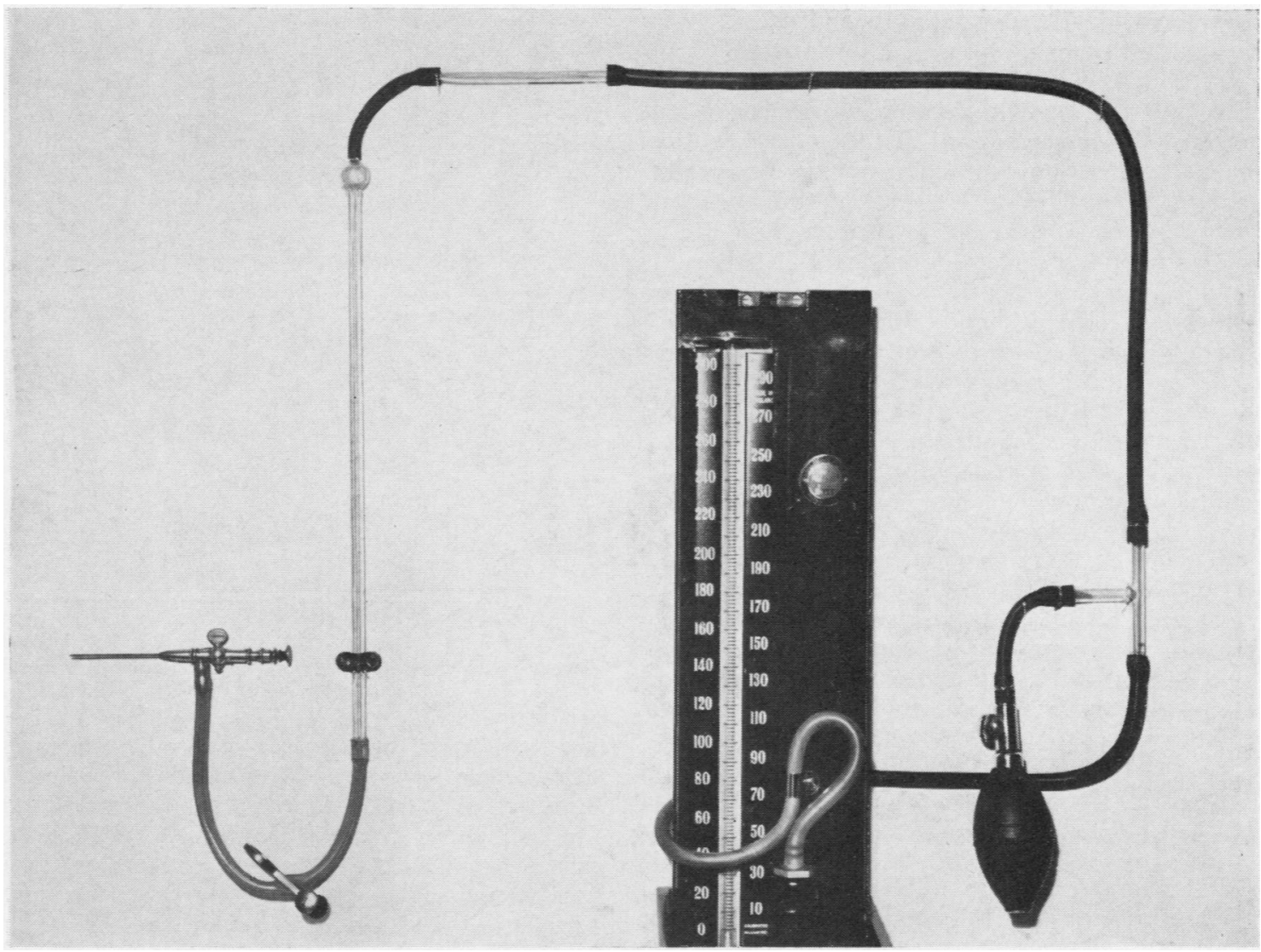

Fig. 1.-Pressure recording apparatus.

TABLE
MEAN JOINT FLUID PRESSURE IN SIXTEEN CASES

\begin{tabular}{|c|c|c|c|c|c|c|c|c|}
\hline \multirow{2}{*}{$\begin{array}{l}\text { Case } \\
\text { No. }\end{array}$} & \multirow{2}{*}{$\begin{array}{c}\text { Duration of } \\
\text { Effusion }\end{array}$} & \multirow{2}{*}{$\underset{\text { (ml.) }}{\text { Volume }}$} & \multicolumn{6}{|c|}{ Pressure $(\mathrm{mm} . \mathbf{H g})$} \\
\hline & & & $\begin{array}{c}\text { At } \\
\text { Rest }\end{array}$ & $\begin{array}{l}\text { Venous Cuff } \\
(70 \mathrm{~mm} . \mathrm{Hg})\end{array}$ & $\begin{array}{l}\text { Quadriceps } \\
\text { Contraction }\end{array}$ & $\begin{array}{c}\text { Leg } \\
\text { Hanging }\end{array}$ & $\begin{array}{l}\text { Weight } \\
\text { Bearing }\end{array}$ & $\begin{array}{c}\text { Leg } \\
\text { Braced }\end{array}$ \\
\hline $\begin{array}{r}1 \\
2 \\
3 \\
4 \\
5 \\
6 \\
7 \\
8 \\
9 \\
10 \\
11 \\
12 \\
13 \\
14 \\
15 \\
16\end{array}$ & $\begin{array}{l}\text { Years } \\
\text { Years } \\
\text { Years } \\
4 \text { mths } \\
\text { Years } \\
\text { Years } \\
\text { Years } \\
\text { Years } \\
\text { Years } \\
\text { Years } \\
\text { Years } \\
\text { Years } \\
\text { Years } \\
2 \text { mths } \\
\text { Years } \\
3 \text { mths }\end{array}$ & $\begin{array}{r}6 \\
15 \\
20 \\
25 \\
25 \\
25 \\
35 \\
35 \\
35 \\
40 \\
45 \\
55 \\
70 \\
70 \\
72 \\
190\end{array}$ & $\begin{array}{l}10 \\
33 \\
16 \\
9 \\
19 \\
10 \\
10 \\
14 \\
18 \\
13 \\
12 \\
6 \\
15 \\
24 \\
11 \\
19\end{array}$ & $\begin{array}{r}7 \\
43 \\
25 \\
17 \\
31 \\
20 \\
32 \\
35 \\
29 \\
14 \\
19 \\
9 \\
62 \\
32 \\
18 \\
40\end{array}$ & $\begin{array}{l}112 \\
223 \\
300 \\
187 \\
240 \\
150 \\
267 \\
300 \\
145 \\
127 \\
157 \\
156 \\
300+ \\
300+ \\
138 \\
300+\end{array}$ & $\begin{array}{r}45 \\
27 \\
22 \\
10 \\
95 \\
27 \\
31 \\
35 \\
42 \\
46 \\
10 \\
9 \\
107 \\
50 \\
16 \\
20\end{array}$ & $\begin{array}{c}50 \\
76 \\
25 \\
22 \\
140 \\
36 \\
130 \\
125 \\
62 \\
68 \\
79 \\
42 \\
103 \\
\text { Not done } \\
29 \\
24\end{array}$ & $\begin{array}{l}141 \\
300+ \\
300+ \\
198 \\
300+\end{array}$ \\
\hline
\end{tabular}

\section{Discussion}

Both venous and interstitial fluid pressure might be expected to play a part in determining the resting or static pressure within the knee joint.
Venous pressure in the normal leg has been extensively studied by Dodd and Cockett (1956). It is equal to the pressure of a column of blood extending from the leg to heart level. This is equivalent to a pressure of between 85 and $90 \mathrm{~mm}$. 
$\mathrm{Hg}$ according to the height of the individual. With competent venous valves and the action of the calf muscles, this pressure quickly falls to between 0 and $10 \mathrm{~mm}$. $\mathrm{Hg}$ (0 to $13 \mathrm{~cm}$. water). Subcutaneous interstitial pressures taken at the ankle in normal subjects in the prone position were found by Day, Hinshaw, and Walder (1960) to lie between 2.5 and $0.2 \mathrm{~mm}$. $\mathrm{Hg}$.

Joint fluid pressures in the normal knee were studied by Müller (1929) who recorded pressures between -2 and $-8 \mathrm{~cm}$. saline in the supine position; in the presence of even a moderate effusion he found a negative pressure. Ranke (1875) found pressures of 5 to $20 \mathrm{~mm}$. $\mathrm{Hg}$ in bloody effusions when recordings were taken in the prone position. Rostock (1929), measuring the pressure in traumatic effusions with volumes of 20 to $60 \mathrm{ml}$. and in pyarthroses and recurrent serous effusions, found values of 0 to $340 \mathrm{~mm}$. water. Ropes and Bauer (1953) found that the intra-articular pressure varied markedly in knee joint effusions and was not related to the aetiology, severity, or duration of the effusion. No studies could be found in which pressure was recorded in different postures, and it therefore seemed of importance to study this.

In the present series pressures at rest recorded in $\mathrm{mm}$. saline were all above zero and ranged between 88 and $500 \mathrm{~mm}$. (i.e. 6.5 to $36.7 \mathrm{~mm}$. $\mathrm{Hg}$ ). It is possible that the negative pressures recorded by Müller in the presence of effusions and the zero pressures recorded by Rostock in the presence of moderate effusions were due to blockage of the recording apparatus. No constant relationship with venous pressure was found. Although all but six patients showed a significant increase in pressure on changing from the supine to the erect posture, the pressure increase was not the same for each patient.

One of us (E.G.L.B.) has shown (unpublished data, 1939) that the volume-pressure curve for the knee-joint cavity (obtained either by progressive aspiration of an effusion or by refilling the emptied cavity with saline) has two components: an initial slope, which is probably dependent on the compression and rearrangement of synovial membrane components within the elastic capsule, and a steeper curve, which represents distension of the capsule (Fig. 2).

In the experiments reported here, the initial starting point was recorded with the full amount of accumulated effusion and might therefore be found anywhere on such a curve. Increments of external compression by muscle or bone maintaining a constant volume, therefore, would produce rather variable increments of intra-articular pressure, according to the degree of distension. An impor-

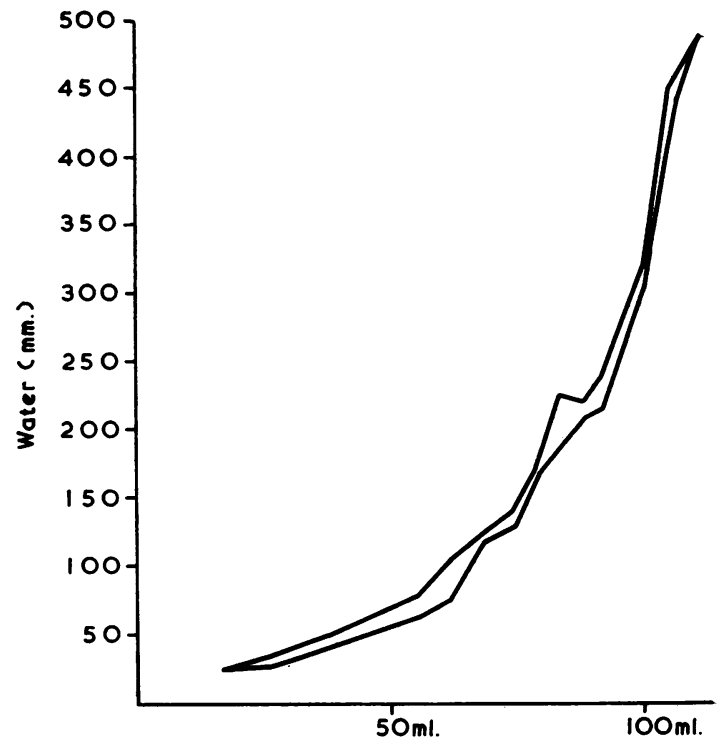

Fig. 2.-Pressure changes within the knee with progressive emptying and filling of the joint cavity.

tant conclusion, however, is that the pressures observed during muscle contraction are almost always above those obtained in the capillaries and arterioles (Fig. 3, opposite). Thus exudation to replace lymph drainage in these patients must be intermittent, and during phases of raised pressure diffusion between the blood stream and the cavity must be impaired.

\section{Summary}

A method is described for measuring the pressure in chronic knee-joint effusions in the supine and erect positions.

Sixteen joints were satisfactorily examined. The resting values varied from 6 to $33 \mathrm{~mm}$. $\mathrm{Hg}$. All showed a marked increase in pressure with quadriceps contraction, and the majority showed an increase on weight bearing.

The factors possibly contributing to joint fluid pressure are briefly discussed.

It is a pleasure to acknowledge the technical assistance of Mr. John Harrison in this study and the help and advice of Dr. Barbara Ansell in the preparation of this paper.

\section{REFERENCES}

Bywaters, E. G. L. (1939). Unpublished data.

Day, S. B., Hinshaw, L. B., and Walder, A. (1960). Irish J. med. Sci., 6th ser., No. 411, p. 148. 

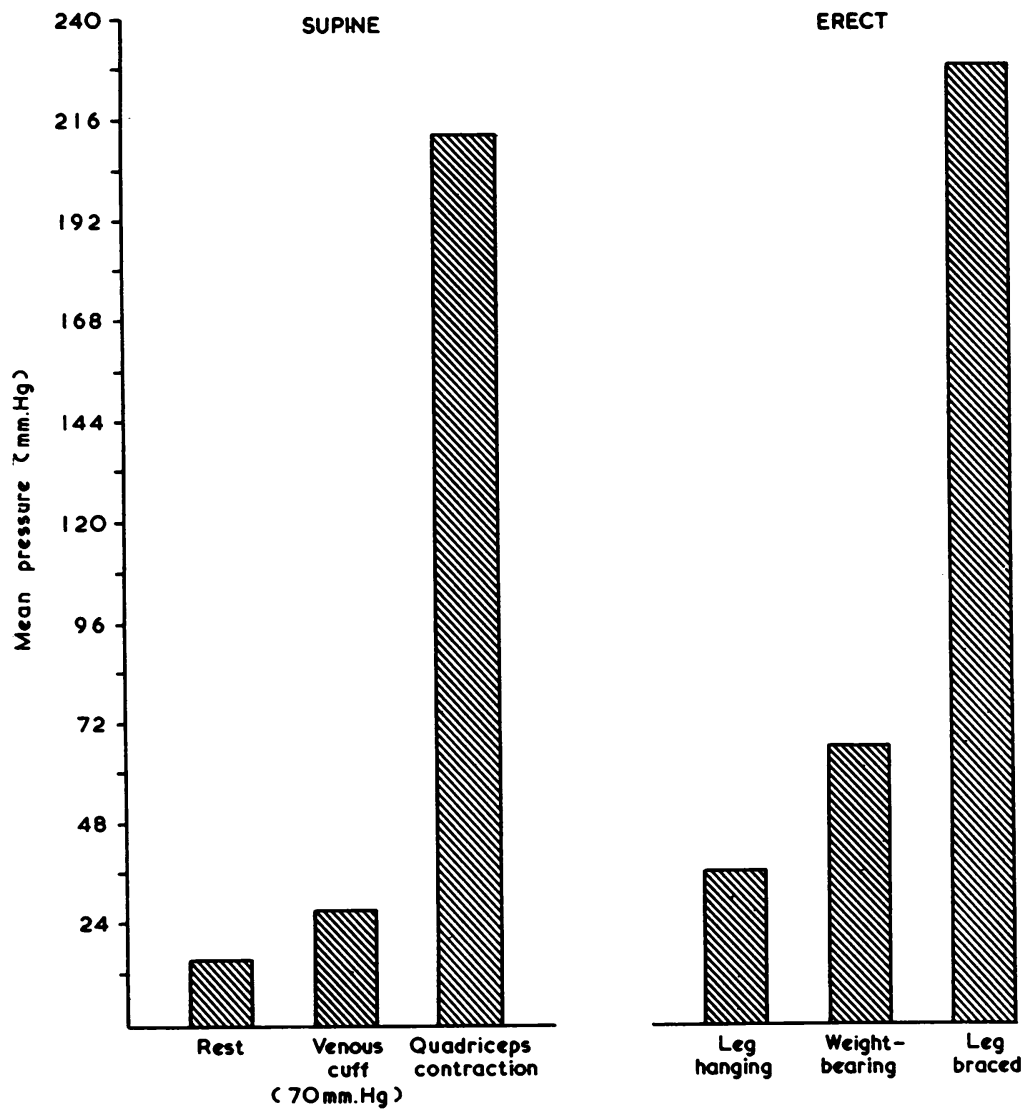

Fig. 3.-Mean pressures in supine and erect position in various circumstances.

Dodd, H., and Cockett, F. B. (1956). "The Pathology and Surgery of the Veins of the Lower Limb." Livingstone, Edinburgh.

Müller, W. (1929). Dtsch. Z. Chir., 218, 395.

Ranke, H. R. (1875). Zbl. Chir., 2, 609.

Ropes, M., and Bauer, W. (1953). "Synovial Fluid Changes in Joint Disease." Harvard University Press, Cambridge, Mass.

Rostock, P. (1929). Dtsch. Z. Chir., 213, 314.

\section{Tension du liquide articulaire dans les épanchements chroniques du genou}

\section{RÉSUMÉ}

On décrit une méthode pour mesurer la tension dans les épanchements chroniques du genou, debout et en supination.

Seize articulations furent examinées d'une manière satisfaisante. Les valeurs en repos variaient entre 6 et $33 \mathrm{~mm}$. de $\mathrm{Hg}$. Toutes les articulations accusaient une augmentation de la tension quand le quadriceps se contractait et la plupart d'entre elles en supportant le poids du corps.

On discute brèvement les facteurs qui peuvent affecter la tension articulaire.

\section{Presión del líquido articular en efusiones crónicas de la rodilla}

\section{SUMARIO}

Se describe un método para medir la presión de las efusiones crónicas de la rodilla en las posiciones erecta y supina.

Dieciseis articulaciones fueron examinadas de una manera satisfactoria. Los valores en reposo variaron de 6 a $33 \mathrm{~mm}$. de $\mathrm{Hg}$. Todos acusaron un marcado aumento de presión al contraerse el cuadriceps y la mayoría acusó un aumento al soportar peso.

Los factores que posiblemente contribuyen a producir la presión articular se discuten brevemente. 